\title{
Donos de terras e escravos no Paraná: padrões e hierarquias nas primeiras décadas do século XIX
}

\author{
Horacio Gutiérrez ${ }^{*}$
}

\begin{abstract}
Resumo:
Nas primeiras décadas do século XIX a repartição da terra no Paraná registrou um alto índice de concentração, com os fazendeiros de gado detendo as maiores propriedades. Neste artigo examina-se o uso da mão-de-obra escrava da parte dos donos da terra, assim como o acesso à terra por parte dos proprietários de escravos. Discutem-se hierarquias sociais presentes na sociedade local e a importância da terra e dos escravos na constituição dessas hierarquias. As fontes primárias empregadas na análise foram cadastros de terras e recenseamentos de população.
\end{abstract}

Palavras-chave: estrutura fundiária, escravidão, Paraná colonial.

No modelo agrário exportador do Brasil colonial o escravo foi a força de trabalho principal. A mão-de-obra familiar, assalariada, agregada e outras formas de emprego de mão-de-obra foram residuais quando se tratou de produção de artigos para exportação. Nas economias de subsistência destinadas aos mercados internos, ou ao consumo próprio, a organização do trabalho mostrou matizes mais variados, conjugando-se à policultura, à apropriação de menores extensões de terras e a modos de acesso a ela mais informais. O escravo, no entanto, definiu também aqui o ponto de inflexão a partir do qual era impossível crescer produtivamente sem contar com o seu concurso, nem aceder a terras devolutas através da solicitação de sesmarias, possibilitando-se assim a ampliação das áreas destinadas à lavoura ou à criação.

Foi esta também a percepção dos recenseadores que elaboraram no Paraná o Inventário dos Bens Rústicos (um cadastro de terras), em 1818, ao requerer dos declarantes a informação sobre o número de escravos que trabalhavam as terras. Não listaram o número de trabalhadores autônomos, assalariados nem agregados, que certamente os havia, mas apenas os cativos, numa demonstração do papel de divisor de águas que a posse desta mão-de-obra representava, mesmo em uma economia pouco escravizada como a do Paraná. O cadastro foi feito ao final da era colonial, em plena fase de expansão da pecuária e numa região com vínculos comerciais acanhados com o 


\section{DONOS DE TERRAS E ESCRAVOS NO PARANÁ}

exterior. Mas a pecuária estruturava circuitos mercantis internos importantes, unia mercados espacialmente afastados que iam do Rio Grande do Sul até São Paulo, Rio de Janeiro e Minas Gerais, e dinamizava indiretamente outros setores vinculados ao comércio, ao artesanato e à agricultura de alimentos.

A produção mercantil voltada para mercados regionais foi a responsável no Paraná pela demanda de terras em abundância e de extensão comprida, desde as primeiras décadas do século XVIII. Junto com ela, como causa e efeito ao mesmo tempo, num processo progressivo de acumulação, veio a procura do escravo. Inicialmente, no século XVII, foi o escravo indígena quem preencheu as necessidades da lavoura e da mineração, e ele mesmo foi capturado como mercadoria para venda em outras regiões. Mas nas primeiras décadas do século XVIII, com a consolidação da pecuária como atividade comercial e a diminuição do índio nas áreas mais próximas, os escravos de origem africana substituíram paulatinamente o indígena.

Não há estimativas confiáveis sobre o número de indígenas escravizados, nem sobre os negros importados até a primeira metade do século XVIII. Romário Martins, com evidente exagero, estima que por volta de 1630, quando os bandeirantes paulistas assaltaram e destruíram as reduções do Guairá, no extremo oeste paranaense, 15.000 indígenas teriam sido mortos nas incursões e 60.000 vendidos e escravizados em São Paulo e nos engenhos de açúcar nordestinos (Martins s/d, p. 70). Outros autores estimaram números menores, em torno de 30.000 índios escravizados no período 15901630, como resultado das ofensivas às reduções jesuítas (Balhana, Machado \& Westphalen, 1969, pp. 53-55). Já o afluxo ao Paraná dos primeiros escravos de origem africana deveu coincidir com a fundação em 1648 de Paranaguá, no litoral, o primeiro núcleo populacional português instalado na região, em decorrência da descoberta de ouro nas redondezas. Não tardou muito e o metal precioso foi também descoberto serra acima, nos campos de Curitiba. Os novos colonos, vindos principalmente de núcleos setentrionais da capitania de São Paulo, trouxeram possivelmente os primeiros escravos negros para trabalhar na extração e lavagem do metal. Em 1720 ambos os arraiais perfaziam "560 casais e 3400 pessoas de confissão", incluindo no cômputo as respectivas freguesias, conforme registra o ouvidor Pardinho em carta endereçada ao rei. ${ }^{1}$ Índios e escravos negros não foram contabilizados. 
Dados permanentes sobre os escravos apareceram na segunda metade do século XVIII, com a elaboração sistemática de recenseamentos, as chamadas listas nominativas de habitantes. Em 1798, no primeiro quadro global reunindo informações de Antonina, Guaratuba, Paranaguá, Castro, Curitiba, Lapa e São José dos Pinhais, isto é, de todas as localidades então existentes, foram relacionados 4.273 cativos dentro de uma população de 20.999 pessoas. O peso relativo de $20,3 \%$ com que os escravos figuraram nesse ano se manteria com poucas variações nas décadas seguintes: 18,6\% em 1810 e 17,1\% em 1830. Neste último ano a população total do Paraná já havia subido a 36.701 habitantes e o contingente de escravos crescera para 6.260 pessoas. As vilas mais escravistas eram as mais vinculadas ao mercado em virtude da pecuária: em Castro os escravos representavam $21,8 \%$ da população em 1810 , e vinte anos depois registrava 26,9\%; o porcentual de Ponta Grossa (freguesia subordinada a Castro) era em 1830 de 19,1\% e o de Palmeira de 31\% (Costa \& Gutiérrez, 1985). A proporção de escravos era baixa, embora similar à existente em outras áreas de economias internas, como era o caso da maior parte das vilas paulistas nessa época e de Minas Gerais durante todo o século XIX. Participação mais significativa, entre 30 e 40\%, verificara-se em zonas com economias de exportação como o Recôncavo baiano ou, em São Paulo, no quadrilátero do açúcar (Luna \& Costa, 1983, p. 213; Paiva \& Klein, 1992, p. 134; Schwartz, 1988, p. 357).

Neste texto nos propomos a examinar o uso de escravos pelos proprietários de terras e a posse de terras por parte dos proprietários de escravos, bem como discutir as diferenciações presentes entre os donos de terras com escravos e os sem escravos. Recorremos para essa análise a informações de cadastros fundiários e recenseamentos de população. A comparação de fontes permitirá desembocar também na visualização de hierarquias sociais, sua complexidade e o papel do escravo na constituição dessas hierarquias.

\section{Escravos nas propriedades}

No Paraná, nem todos os proprietários de terras possuíam escravos. Na verdade, chama a atenção o extraordinário número de proprietários sem escravos. Reunindo todos os donos de terras do litoral e do planalto, mais de três quartos declararam em 1818 não 


\section{DONOS DE TERRAS E ESCRAVOS NO PARANÁ}

recorrer ao trabalho escravo para as lides agrícolas ou pastoris. A participação dos escravos variava de acordo com as localidades e, mais claramente, com a atividade econômica principal existente nessas localidades. Em Castro e Palmeira, núcleos essencialmente pecuaristas, situava-se o maior percentual de proprietários com escravos residentes, 52,4\% e 39\% respectivamente. Em Antonina e Paranaguá, no litoral, as propriedades com escravos alcançavam $30,5 \%$ e $20,3 \%$ respectivamente, sendo que o valor acima da média da primeira vila devia-se possivelmente à presença de engenhos de arroz e numerosas engenhocas de cana e aguardente na localidade (ver tabela 1).

O número de escravos que registra o inventário de bens rústicos é, no entanto, bem menor que o esperado, a julgar pela população escrava que fora recenseada nas listas nominativas de habitantes, que englobou a totalidade dos domicílios. Segundo as listas nominativas de 1817 , que contaram a população total, o número de escravos no Paraná era de 5.174 indivíduos, e não 2.345 , como consta no inventário de terras. ${ }^{2}$ Da mesma forma, o confronto entre o número de domicílios com escravos e o número de proprietários de terras com escravos mostrou também uma acentuada disparidade, com larga vantagem para os primeiros.

Tabela 1 - Proprietários de terras com escravos no Paraná, 1818

\begin{tabular}{lcccc}
\hline Localidades & $\begin{array}{c}\mathrm{N}^{\circ} \text { total } \\
\text { propriedades }\end{array}$ & $\begin{array}{c}\text { Propriedades } \\
\text { com } \\
\text { escravos }\end{array}$ & $\begin{array}{c}\% \text { com } \\
\text { escravos }\end{array}$ & $\begin{array}{c}\text { N. total } \\
\text { escravos }\end{array}$ \\
\hline Litoral & & & & \\
Antonina & 262 & 80 & 30,5 & 380 \\
Guaratuba & 91 & 11 & 12,1 & 43 \\
Paranaguá & 428 & 87 & 20,3 & 483 \\
Planalto & & & & \\
Castro & 231 & 121 & 52,4 & 758 \\
Curitiba & 522 & 58 & 11,1 & 202 \\
Lapa & 183 & 54 & 29,5 & 213 \\
Palmeira & 146 & 57 & 39,0 & 232 \\
São José & 205 & 15 & 7,3 & 34 \\
Paraná & 2068 & 483 & 23,4 & 2345 \\
\hline
\end{tabular}

Foi excluída uma propriedade da Lapa que não indicou se tinha ou não escravos. Fonte: Arquivo do Estado de São Paulo, Inventário dos Bens Rústicos, 1818. 
Essas discrepâncias são intrigantes e não decorrem de erro estatístico. Interessante é analisá-la, e o faremos a seguir, porque elas permitem iluminar a inserção dos cativos na estrutura social vigente, e também podem desvendar padrões de posse de terras e escravos, com implicações valiosas. As discrepâncias poderiam ser interpretadas de duas maneiras: 1) O inventário de estabelecimentos rurais contabilizou apenas escravos em idade produtiva, que efetivamente trabalhavam a terra, excluindo as crianças; e 2) Muitos donos de escravos não eram proprietários de terras. Ambas as possibilidades podem ser examinadas de maneira aproximada.

No primeiro caso é possível confrontar o inventário com as listas nominativas de habitantes, retirando as crianças da população escrava que constou nas últimas. Até que idade uma pessoa era considerada criança? Ou, quando uma pessoa começava a ser considerada economicamente produtiva? Não é fácil saber, pois se bem a idade é indicada nas fontes, não consta a ocupação que os escravos exerciam, de modo que não é possível deduzir a idade com a qual os cativos começavam a ser requisitados na lavoura, na pecuária e nos serviços. ${ }^{3}$ Adotando o critério arbitrário de considerar adultos (economicamente) os escravos com 10 ou mais anos, o número de escravos produtivos (sem crianças) nas listas nominativas seria de 3.766 no conjunto das vilas do Paraná, número este mais próximo dos 2.345 que constam no inventário de terras (ver tabela 2). Parte da diferença poderia ser atribuída ainda a escravos idosos - de propriedade dos donos de terras - que já não exerciam ocupações. Ou seja, é possível pensar que os escravos dos proprietários de terras relacionados no inventário sejam apenas os produtivos e que os não produtivos não foram arrolados. Ainda assim a explicação seria insuficiente para dar conta da diferença remanescente. 
Tabela 2 - Número de escravos dos proprietários de terras e no conjunto dos domicílios do Paraná, 1817-18

\begin{tabular}{lccc}
\hline Localidades & $\begin{array}{c}\text { N. total de } \\
\text { escravos dos } \\
\text { proprietários de } \\
\text { terras em 1818 }\end{array}$ & $\begin{array}{c}\text { N. total de } \\
\text { escravos nos } \\
\text { domicílios em } \\
1817\end{array}$ & $\begin{array}{c}\text { N. de escravos } \\
\text { adultos nos } \\
\text { domicílios em } \\
1817\end{array}$ \\
\hline Litoral & & & \\
Antonina & 380 & 837 & 579 \\
Guaratuba & 43 & 110 & 81 \\
Paranaguá & 483 & 1099 & 860 \\
Planalto & & & \\
Castro & 758 & 1138 & 617 \\
Curitiba & 202 & 841 & 292 \\
Lapa & 213 & 418 & 335 \\
Palmeira & 232 & 242 & 180 \\
São José & 34 & 5174 & 3766 \\
Paraná & 2345 & & \\
\hline
\end{tabular}

Foram considerados adultos os escravos com 10 ou mais anos.

Fonte: Arquivo do Estado de São Paulo, Inventário dos Bens Rústicos, 1818, e Listas Nominativas de Habitantes, 1817.

A outra opção é pensar que o inventário de terras listou os escravos integralmente, ou seja, incluindo adultos e crianças, sem omissões, ou com omissões mínimas, e a diferença atribuir-se então, total ou principalmente, à segunda alternativa antes mencionada.

Analisar essa segunda alternativa - a existência de donos de escravos sem terras - chama a atenção porque, se verdadeira, levantaria indagações de muita importância. O exame de segmentos sociais habituais como proprietários de terras, donos de escravos, famílias sem terras e sem escravos e, na base, os cativos e indígenas, desenha uma pirâmide social, mas apenas refletiria os extremos. Aceitar a existência de escravistas sem terras significa que a sociedade possuía uma estratificação mais complexa, com segmentos, no Paraná, até agora desconhecidos. Quem teriam sido esses escravistas sem terras? Foram numericamente significativos? Em quais setores econômicos teriam sido mais freqüentes? O confronto do recenseamento (listas nominativas) de 1817 com o inventário de terras de 1818 permite captar alguns pormenores. 
Segundo as listas nominativas que arrolaram as características demográficas e sociais de todos os domicílios, incluídos os donos de escravos, havia em 1817 no Paraná 5.148 domicílios. Já no inventário de bens rústicos de 1818 constaram 2.068 proprietários de terras. Supondo que cada proprietário de terras conformava também um domicílio, havia então $40 \%$ de domicílios com terras próprias e, portanto, $60 \%$ sem terras. $^{4}$

Por outro lado, contando nas listas nominativas apenas os domicílios com escravos, chegou-se a um total de 1.011 domicílios. O mesmo cômputo feito no inventário, isto é, de apenas os proprietários de terras com escravos, registrou um total de 483 proprietários. Seguindo o raciocínio, deduz-se que o número de domicílios escravistas com terras (483) equivalia a cerca da metade do total $(1011)^{5}$, ou mais precisamente $47,8 \%$, e portanto o saldo, a saber, 52,2\%, correspondia a donos de escravos sem terras (ver tabela 3 ).

Tabela 3 - Número de domicílios e de propriedades rurais no Paraná, 1817-18

\begin{tabular}{lcccccc}
\hline Localidades & $\begin{array}{c}\text { (A) } \\
\text { Número } \\
\text { total de } \\
\text { domicílios }\end{array}$ & $\begin{array}{c}\text { N. de } \\
\text { domicílios } \\
\text { com } \\
\text { escravos }\end{array}$ & $\begin{array}{c}\text { Número } \\
\text { de } \\
\text { proprie- } \\
\text { dades } \\
\text { rurais }\end{array}$ & $\begin{array}{c}\text { N. de } \\
\text { proprie- } \\
\text { dades rurais } \\
\text { com } \\
\text { escravos }\end{array}$ & $\begin{array}{c}\text { Domicílios } \\
\text { com terras } \\
(\mathrm{C}) /(\mathrm{A})\end{array}$ & $\begin{array}{c}\text { Escravistas } \\
\text { com terras } \\
(\mathrm{D}) /(\mathrm{B})\end{array}$ \\
\hline Litoral & \multicolumn{7}{c}{} & & \\
Antonina & 731 & 139 & 262 & 80 & 35,8 & 57,6 \\
Guaratuba & 136 & 23 & 91 & 11 & 66,9 & 47,8 \\
Paranaguá & 1087 & 213 & 428 & 87 & 39,4 & 40,8 \\
Planalto & & & & & & \\
Castro & 747 & 206 & 231 & 121 & 30,9 & 58,7 \\
Curitiba & 1180 & 178 & 522 & 58 & 44,2 & 32,6 \\
Lapa & 479 & 75 & 183 & 54 & 38,2 & 72,0 \\
Palmeira & 328 & 95 & 146 & 57 & 44,5 & 60,0 \\
São José & 460 & 82 & 205 & 15 & 44,6 & 18,3 \\
Paraná & 5148 & 1011 & 2068 & 483 & 40,2 & 47,8 \\
\hline
\end{tabular}

Os dados dos domicílios são de 1817 e os das propriedades rurais de 1818 .

Foi excluída uma propriedade da Lapa que não indicou se tinha ou não escravos.

Fonte: Arquivo do Estado de São Paulo, Listas Nominativas de Habitantes, 1817, e Inventário dos Bens Rústicos, 1818. 
As considerações anteriores permitem identificar quatro categorias de chefes de domicílios em relação às variáveis terra e escravos. Colocadas em ordem crescente segundo o peso quantitativo, as categorias seriam as seguintes:

1) Chefes de domicílios com terras e com escravos. Totalizavam 483 casos ou $9,4 \%$ do total, estando mais bem representados em Castro e Palmeira. Seria a elite da elite no Paraná;

2) Chefes de domicílios sem terras e com escravos. Reuniam um conjunto de 528 chefes ou $10,3 \%$ do total;

3) Chefes de domicílios com terras e sem escravos. Compreendiam 1.585 chefes ou $30,8 \%$ do universo pesquisado;

4) Chefes de domicílios sem terras e sem escravos. Inseriam-se nesta categoria 2.552 domicílios do total de 5.148 no Paraná, ou 49,6\% do conjunto (ver tabela 4).

Tabela 4 - Categorias sociais no Paraná em relação as variáveis terra e escravos, 181718

\begin{tabular}{|c|c|c|c|c|c|c|}
\hline Localidades & $\begin{array}{c}\text { \% Chefes } \\
\text { de } \\
\text { domicílio } \\
\text { com terras e } \\
\text { com } \\
\text { escravos }\end{array}$ & $\begin{array}{c}\text { \% Chefes } \\
\text { de } \\
\text { domicílio } \\
\text { sem terras e } \\
\text { com } \\
\text { escravos }\end{array}$ & $\begin{array}{c}\text { \% Chefes } \\
\text { de } \\
\text { domicílio } \\
\text { com terras e } \\
\text { sem } \\
\text { escravos }\end{array}$ & $\begin{array}{c}\text { \% Chefes } \\
\text { de } \\
\text { domicílio } \\
\text { sem terras e } \\
\text { sem } \\
\text { escravos }\end{array}$ & Total & $\begin{array}{l}\text { Número de } \\
\text { domicílios }\end{array}$ \\
\hline \multicolumn{7}{|l|}{ Litoral } \\
\hline Antonina & 10,9 & 8,1 & 24,9 & 56,1 & 100,0 & $(731)$ \\
\hline Guaratuba & 8,1 & 8,8 & 58,8 & 24,3 & 100,0 & (136) \\
\hline Paranaguá & 8,0 & 11,6 & 31,4 & 49,0 & 100,0 & (1087) \\
\hline \multicolumn{7}{|l|}{ Planalto } \\
\hline Castro & 16,2 & 11,4 & 14,7 & 57,7 & 100,0 & $(747)$ \\
\hline Curitiba & 4,9 & 10,2 & 39,3 & 45,6 & 100,0 & (1180) \\
\hline Lapa & 11,3 & 4,4 & 26,9 & 57,4 & 100,0 & $(479)$ \\
\hline Palmeira & 17,4 & 11,6 & 27,1 & 43,9 & 100,0 & (328) \\
\hline São José & 3,3 & 14,6 & 41,3 & 40,8 & 100,0 & $(460)$ \\
\hline Paraná & 9,4 & 10,3 & 30,8 & 49,6 & 100,0 & $(5148)$ \\
\hline $\begin{array}{l}\mathrm{N}^{\mathrm{o}} \\
\text { domicílios }\end{array}$ & (483) & $(528)$ & (1585) & (2552) & $\begin{array}{r}(5148 \\
)\end{array}$ & \\
\hline
\end{tabular}


Obs.: Os cálculos foram feitos a partir da tabela 3, da seguinte forma:

- \% chefes de domicílio com terras e com escravos: colunas D/A.

- \% chefes de domicílio sem terras e com escravos: colunas (B - D)/A.

- \% chefes de domicílio com terras e sem escravos: colunas $(\mathrm{C}-\mathrm{D}) / \mathrm{A}$.

- \% chefes de domicílio sem terras e sem escravos: por resíduo, ou $(\mathrm{A}-\mathrm{B})-(\mathrm{C}-\mathrm{D}) / \mathrm{A}$.

Fonte: Tabela 3.

Correspondia essa ordem a uma efetiva pirâmide social, de riqueza, posição social ou poder? A resposta seguramente é positiva, mas ela não é óbvia e demanda análises diversas. Para uma hierarquia de riqueza, por exemplo, seriam necessárias informações adicionais com as quais não contamos. Conhecer o valor dos escravos e das terras, e o peso de ambas variáveis no conjunto do patrimônio, permitiria uma aproximação ao tema, que seria possível desenvolver recorrendo, entre outras fontes, a inventários. Pesquisas com estas fontes realizadas para outras regiões indicam um peso importante dos escravos no patrimônio, e bem menos da terra. ${ }^{6}$ Se resultados como esses forem também válidos para o Paraná da época, os escravistas sem terras teriam precedido, efetivamente, num ranking de riqueza, os donos de terras sem escravos, como na lista anterior. Paradoxal mesmo é entender como uma categoria rica (e eventualmente poderosa), como a dos escravistas, pôde existir sem posse de terra, mas apenas de cativos, e como teria se relacionado com os donos da terra e os demais segmentos sociais.

Estes escravistas sem terras teriam sido proporcionalmente mais numerosos - em relação ao conjunto de senhores de escravos - em Curitiba, São José dos Pinhais e Paranaguá. Tratou-se possivelmente de escravistas de poucos escravos, arrendatários, agregados, casais jovens que receberam de seus pais cativos como dote e que residiam em casas cedidas pela família, vinculados aqueles e estes a ocupações agrícolas de subsistência, à erva-mate, ofícios urbanos ou serviços em geral. Nos núcleos mais pecuaristas, como Castro, Lapa e Palmeira, os escravistas sem terras revelaram peso menor dentro da classe formada pelos senhores de escravos.

Outra hipótese explicativa não excludente, embora menos provável, é que os escravistas sem terras foram escravistas urbanos, de poucos escravos e talvez donos de glebas urbanas que não constaram do inventário de bens rústicos. $\mathrm{O}$ inventário registrara principalmente imóveis rurais, mas os numerosos pequenos sítios que também foram consignados levam a pensar que propriedades urbanas ou da periferia urbana tenham 


\section{DONOS DE TERRAS E ESCRAVOS NO PARANÁ}

sido igualmente incluídos. ${ }^{7}$ Mesmo assim, proprietários urbanos foram em geral donos também de terras rurais onde seus escravos trabalhavam, de onde obtinham o sustento e inclusive o dinheiro necessário para adquirir cativos. Sendo assim, boa parte teria sido contemplada no levantamento realizado pelo inventário.

Enfim, a hipótese da existência de proprietários de terras sem escravos parecenos que não deve ser desconsiderada, mesmo em face dos argumentos contrários anteriormente expostos. O saldo final, levando em conta esses argumentos, não anularia a existência de proprietários com essa característica, mas talvez diminuísse a sua incidência (não 10,3\%, mas uma proporção menor).

O inventário nos permite conhecer também a distribuição dos cativos entre os proprietários de terras. Mais de três quartos, como vimos, não possuíam escravos. Entre os com escravos, a maioria $(15,3 \%)$ detinha entre um e quatro escravos, reunindo $31,3 \%$ do conjunto dos cativos. Os que possuíam entre 5 e 19 escravos representavam 7,3\% dos proprietários de terras e apropriavam-se de $52,1 \%$ da população cativa. Finalmente, os proprietários de terras mais aquinhoados de escravos possuíam entre 20 e 60, detendo $16,6 \%$ do total, sendo estes proprietários pouco numerosos, 15 ao todo, ou $0,7 \%$ do conjunto (ver tabela 5).

Tabela 5 - Distribuição dos escravos entre os proprietários de terras no Paraná, 1818

\begin{tabular}{crrrrr}
\hline $\begin{array}{l}\text { Tamanho } \\
\text { da posse de } \\
\text { escravos }\end{array}$ & $\begin{array}{c}\text { N. } \\
\text { propriedades } \\
\text { rurais }\end{array}$ & $\%$ & $\begin{array}{c}\text { N. } \\
\text { escravos }\end{array}$ & $\%$ & $\begin{array}{c}\text { Média de } \\
\text { escravos }\end{array}$ \\
\hline 0 & 1585 & 76,6 & 0 & 0,0 & 0 \\
1 & 92 & 4,4 & 92 & 3,9 & 1 \\
2 & 91 & 4,4 & 182 & 7,8 & 2 \\
3 & 76 & 3,7 & 228 & 9,7 & 3 \\
4 & 58 & 2,8 & 232 & 9,9 & 4 \\
& & & & & \\
1 a 4 & 317 & 15,3 & 734 & 31,3 & 2,3 \\
5 a 9 & 114 & 5,5 & 763 & 32,5 & 6,7 \\
10 a 19 & 37 & 1,8 & 459 & 19,6 & 12,4 \\
20 a 60 & 15 & 0,7 & 389 & 16,6 & 25,9 \\
& & & & & \\
Total & 2068 & 100,0 & 2345 & 100,0 & 1,1 \\
\hline
\end{tabular}

Foi excluída uma propriedade da Lapa que não indicou se tinha ou não escravos. Fonte: Arquivo do Estado de São Paulo, Inventário dos Bens Rústicos, 1818. 


\section{Propriedades com e sem escravos}

A posse de escravos representava uma evidente vantagem nas possibilidades de produção ante os que não os possuíam. Se bem o trabalho familiar estava muito disseminado no Paraná em razão do número expressivo de proprietários de terras sem escravos, a obtenção de mão-de-obra adicional cativa significava abrir efetivamente as portas de ingresso à economia mercantil com produção dirigida ao mercado. Essa possibilidade vê-se corroborada quando comparadas as áreas dos estabelecimentos detidos pelos proprietários de terras que empregavam escravos com os que não os utilizavam. As diferenças eram marcantes. Enquanto a área média das propriedades com escravos era de 3.235 hectares, a área das que não tinham cativos chegava à média de 250 ha (ver tabela 6). Novamente as localidades votadas à pecuária absorviam as propriedades escravistas de maior extensão, com Castro, o principal centro de fazendas de gado, no topo, onde a área média era de 8.044 ha nos imóveis com escravos e 705 ha nos sem cativos. A venda de gado vacum e cavalar constituía o item principal das receitas privadas no Paraná, acima de qualquer outro produto agrícola, e para a população local era o setor dinâmico da economia ao qual se aspirava ingressar. Representava a possibilidade mais favorável de acumulação e portanto de compra de escravos adicionais e crescimento material. O setor era responsável pela ocupação da maior parte da superfície agrícola do Paraná, e Castro e suas fazendas de criar concentravam 57\% dessa superfície (Gutiérrez, 2004). A apropriação por agentes privados das terras devolutas em direção ao oeste, nos campos de Guarapuava e Palmas, processo contínuo durante a primeira metade do século XIX, ocorria precisamente para a implantação de novas fazendas de criar. 
Tabela 6 - Área média das propriedades rurais com e sem escravos no Paraná, 1818

\begin{tabular}{lrrrrrrr}
\hline \multirow{2}{*}{ Localidades } & \multicolumn{5}{c}{ Área média das propriedades rurais (ha) } & \multirow{2}{*}{$\begin{array}{c}\text { Área total } \\
\text { (ha) }\end{array}$} \\
\cline { 2 - 5 } & \multicolumn{2}{c}{ Com escravos } & \multicolumn{2}{c}{ Sem escravos } & Ambas & \\
\hline Litoral & & & & & & & \\
Antonina & 261 & $(76)$ & 75 & $(177)$ & 131 & $(253)$ & 33.097 \\
Guaratuba & 425 & $(11)$ & 62 & $(80)$ & 106 & $(91)$ & 9.663 \\
Paranaguá & 1.373 & $(58)$ & 31 & $(307)$ & 244 & $(365)$ & 89.017 \\
Planalto & & & & & & & \\
Castro & 8.044 & $(121)$ & 705 & $(110)$ & 4.550 & $(231)$ & 1.050 .963 \\
Curitiba & 992 & $(58)$ & 265 & $(464)$ & 346 & $(522)$ & 180.431 \\
Lapa & 1.773 & $(54)$ & 496 & $(127)$ & 877 & $(181)$ & 158.795 \\
Palmeira & 3.569 & $(57)$ & 315 & $(88)$ & 1.594 & $(145)$ & 231.194 \\
São José & 1.428 & $(15)$ & 352 & $(190)$ & 431 & $(205)$ & 88.265 \\
Paraná & 3.235 & $(450)$ & 250 & $(1543)$ & 924 & $(1993)$ & 1.841 .425 \\
\hline
\end{tabular}

Entre parênteses, consta o número de propriedades consideradas no cálculo.

Excluídas 76 propriedades rurais com área não delimitada, das quais 33 com escravos, 42 sem escravos e 1 na qual não consta o número de escravos.

Fonte: Arquivo do Estado de São Paulo, Inventário dos Bens Rústicos, 1818.

A distribuição dos escravos entre propriedades de diferentes tamanhos de área revela, numa visão de conjunto, que havia padrões perfeitamente identificáveis. As propriedades de menores dimensões quase não empregavam escravos, mas, conforme a área ia aumentando, maior era o número relativo de propriedades que utilizavam o serviço de escravos. No grupo das micropropriedades, com 20 ha ou menos, 92,5\% não possuíam escravos. Já entre os latifúndios, com 5000 ha ou mais, apenas 16,7\% não contavam com o auxílio de cativos. Nos estratos intermediários de área o percentual de propriedades sem escravos ia decrescendo harmonicamente conforme aumentava a superfície dos imóveis (tabela 7). Também a média de escravos utilizados crescia paralelamente com a dimensão da propriedade, mas deve-se ressalvar que alguns latifúndios (provavelmente improdutivos) não contaram com cativos. De qualquer modo a tendência indica que os proprietários de terras com maiores áreas eram também os que detinham as maiores posses de escravos. No Paraná os donos de lotes de 100 ha apresentaram uma média de 1 cativo por imóvel, enquanto os proprietários de terrenos com 5000 ha ou mais detinham em média 9 escravos. 
Tabela 7 - Escravos nas propriedades rurais do Paraná segundo estratos de área, 1818

\begin{tabular}{|c|c|c|c|c|c|c|c|}
\hline $\begin{array}{c}\text { Estratos } \\
\text { de área } \\
\text { (ha) }\end{array}$ & $\begin{array}{l}\text { Total de } \\
\text { proprie- } \\
\text { dades }\end{array}$ & $\begin{array}{c}\text { N. } \\
\text { proprie- } \\
\text { dades } \\
\text { sem } \\
\text { escravos }\end{array}$ & $\begin{array}{c}\% \\
\text { proprie- } \\
\text { dades } \\
\text { sem } \\
\text { escravos }\end{array}$ & $\begin{array}{c}\text { N. } \\
\text { proprie- } \\
\text { dades } \\
\text { com } \\
\text { escravos }\end{array}$ & $\begin{array}{c}\% \\
\text { proprie- } \\
\text { dades } \\
\text { com } \\
\text { escravos }\end{array}$ & $\begin{array}{c}\text { N. de } \\
\text { escravos }\end{array}$ & $\begin{array}{c}\text { Média } \\
\text { de } \\
\text { escravos } \\
\text { por pro- } \\
\text { priedade }\end{array}$ \\
\hline$<20$ & 815 & 754 & 92,5 & 61 & 7,5 & 177 & 0,2 \\
\hline 20 a 99 & 455 & 359 & 78,9 & 96 & 21,1 & 391 & 0,9 \\
\hline 100 a 999 & 449 & 306 & 68,2 & 143 & 31,8 & 619 & 1,4 \\
\hline 1000 a 4999 & 226 & 116 & 51,3 & 110 & 48,7 & 556 & 2,5 \\
\hline 5000 a 130000 & 48 & 8 & 16,7 & 40 & 83,3 & 438 & 9,1 \\
\hline Total & 1993 & 1543 & 77,4 & 450 & 22,6 & 2181 & 1,1 \\
\hline
\end{tabular}

Excluídas 76 propriedades com área não delimitada, das quais 42 sem escravos, 33 com escravos e 1 na qual não consta o número de escravos. Nas 33 com escravos residiam 164 cativos também aqui excluídos.

Fonte: Arquivo do Estado de São Paulo, Inventário dos Bens Rústicos, 1818.

Esse aumento foi típico de regiões de grande lavoura e de pecuária, conforme constatou Canabrava (1976, pp. 22-26) para a capitania de São Paulo. Significa que os escravos nessas economias viviam principalmente nas grandes propriedades, diferentemente das zonas com domínio de culturas de subsistência, nas quais o crescimento no número de escravos estagnava nas propriedades de faixas intermediárias, residindo a maior parcela dos cativos em imóveis pequenos e médios. No Paraná também comprovamos este fato ao separarmos os escravos do litoral, votados principalmente à pequena lavoura, dos do planalto, onde predominava a pecuária. Os primeiros residiam em sua maior parte em pequenas e médias propriedades; os segundos viviam em sua maioria em estabelecimentos de porte médio e grande.

A distribuição da terra entre proprietários com e sem escravos era claramente desigual, com larga vantagem para os primeiros. Dos 1.841.425 ha ocupados do Paraná, 1.455.611 ha - cerca de 79\% - estavam em posse dos proprietários com escravos, sendo que eles representavam 22,6\% do total, ao passo que os não proprietários de escravos, que alcançavam 77,4\% do total, apropriavam-se de 385.814 ha, ou seja, $21 \%$ das terras (tabela 8). Examinando a distribuição separadamente para cada tipo de proprietário percebe-se que entre os com escravos apenas 34,9\% tinham imóveis com menos de 100 


\section{DONOS DE TERRAS E ESCRAVOS NO PARANÁ}

ha, contra $65,1 \%$ entre os proprietários sem escravos. Nas propriedades acima de 1000 ha os donos com escravos atingiam o porcentual de 33,3\% e os sem escravos chegavam somente a $8 \%$.

Tabela 8 - Distribuição da terra entre as propriedades rurais com e sem escravos no Paraná, 1818

\begin{tabular}{|c|c|c|c|c|c|}
\hline $\begin{array}{l}\text { Estratos de área } \\
\text { (ha) }\end{array}$ & $\begin{array}{c}\mathrm{N} . \\
\text { propriedades }\end{array}$ & $\%$ & $\begin{array}{l}\text { Área total } \\
\text { (ha) }\end{array}$ & $\%$ & $\begin{array}{l}\text { Área média } \\
\text { (ha) }\end{array}$ \\
\hline \multicolumn{6}{|l|}{$\begin{array}{l}\text { 1. Propriedades } \\
\text { com escravos }\end{array}$} \\
\hline$<20$ & 61 & 13,6 & 528 & 0,1 & 9 \\
\hline 20 a 99 & 96 & 21,3 & 4.968 & 0,3 & 52 \\
\hline 100 a 999 & 143 & 31,8 & 53.312 & 3,7 & 373 \\
\hline 1000 a 4999 & 110 & 24,4 & 237.563 & 16,3 & 2.160 \\
\hline 5000 a 130000 & 40 & 8,9 & 1.159 .240 & 79,6 & 28.981 \\
\hline Total & 450 & 100,0 & 1.455 .611 & 100,0 & 3.235 \\
\hline \multicolumn{6}{|l|}{$\begin{array}{l}\text { 2. Propriedades } \\
\text { sem escravos }\end{array}$} \\
\hline$<20$ & 754 & 48,9 & 4.397 & 1,1 & 6 \\
\hline 20 a 99 & 359 & 23,3 & 18.559 & 4,8 & 52 \\
\hline 100 a 999 & 306 & 19,8 & 99.901 & 25,9 & 327 \\
\hline 1000 a 4999 & 116 & 7,5 & 196.407 & 50,9 & 1.693 \\
\hline 5000 a 130000 & 8 & 0,5 & 66.550 & 17,3 & 8.319 \\
\hline Total & 1543 & 100,0 & 385.814 & 100,0 & 250 \\
\hline \multicolumn{6}{|l|}{$\begin{array}{l}\text { 3. Todas as } \\
\text { propriedades }\end{array}$} \\
\hline$<20$ & 815 & 40,9 & 4.925 & 0,3 & 6 \\
\hline 20 a 99 & 455 & 22,8 & 23.527 & 1,3 & 52 \\
\hline 100 a 999 & 449 & 22,5 & 153.212 & 8,3 & 341 \\
\hline 1000 a 4999 & 226 & 11,3 & 433.971 & 23,6 & 1.920 \\
\hline 5000 a 130000 & 48 & 2,4 & 1.225 .790 & 66,6 & 25.537 \\
\hline Total & 1993 & 100,0 & 1.841 .425 & 100,0 & 924 \\
\hline
\end{tabular}

Excluídas 76 propriedades com área não delimitada, das quais 33 com escravos, $42 \mathrm{sem}$ escravos e 1 na qual não consta o número de escravos.

Fonte: Arquivo do Estado de São Paulo, Inventário dos Bens Rústicos, 1818.

Os padrões díspares encontrados no que se refere à repartição da terra e escravos explicam-se pelo uso diferenciado que os proprietários faziam dessa terra e desses 
escravos. Os conceitos firmados sobre as economias de criação de gado e de subsistência são básicos para compreender os padrões, sua articulação entre si e a dinâmica do crescimento. O escravo aparece como elemento-chave na diferenciação, sendo seu emprego explicado em função de sua inserção em atividades econômicas voltadas para o mercado interno. Nas atividades não mercantis, de subsistência ou de trocas residuais, o escravo aparecia menos e a terra necessária para a produção não era mais, como regra, a grande propriedade.

A demografia dos escravos também mostra no Paraná peculiaridades interessantes. Diferentemente das economias de grande lavoura, como as votadas à exportação de açúcar e café, a população escrava paranaense nesta época registrou padrões de crescimento endógenos, nos quais a reprodução natural teve uma importância bem maior que a compra de africanos. Nas primeiras décadas do século XIX, período para o qual existem informações mais precisas, a população cativa local cresceu a taxas anuais de 1,2\%, com destaque para os escravos em idade produtiva, principalmente entre os 10 e 40 anos. Na explicação desse crescimento os africanos mostram-se pouco presentes. Em Castro, numa amostra do funcionamento do mercado de escravos durante quatro anos seguidos, $70 \%$ dos cativos transacionados foram crioulos (nascidos no Brasil), e 30\% africanos. Na população cativa de Castro havia seis crioulos para cada africano. Em Antonina a proporção era de oito a um. O predomínio de crioulos era incontestável e outros indicadores demográficos ajudam a completar o perfil dos padrões vigentes. Entre 1804 e 1830 o porcentual de homens na população escrava total oscilou entre 49 e $51 \%$, revelando que o equilíbrio entre os sexos foi a regra. As pirâmides de idades mostram desenhos triangulares parecidos ao de uma população normal, com base larga nas faixas etárias iniciais. De fato, a crianças com nove anos ou menos representavam $27 \%$ da população total. Finalmente, os índices de casamento entre os escravos chegaram a valores entre 20 e $25 \%$, muito acima do constatado para qualquer região de grande lavoura. Esses índices aumentavam com o tamanho das posses, chegando a $40 \%$ nos plantéis com 40 ou mais escravos (Gutiérrez, 1987, pp. 297-314; e 1988, pp. 161-188).

O que os indicadores sugerem é que a formação de famílias e a criação de filhos foi o fator principal no crescimento da população escrava do Paraná, sendo residual a importação de africanos. Foi nas grandes propriedades que a formação de famílias 


\section{DONOS DE TERRAS E ESCRAVOS NO PARANÁ}

escravas teve mais possibilidades de se efetivar e foi de fato onde mais se constituíram. Em comparação com as pequenas propriedades, nas grandes os crioulos foram numericamente mais significativos, os índices de casamento maiores, e, em contrapartida, a compra de escravos no mercado revelara-se mais acanhada.

\section{O escravo e o uso da terra}

O inventário de terras de 1818 permite avançar também em alguns aspectos sobre o uso que os grandes e pequenos proprietários davam à terra. Indiretamente também é possível deduzir de modo genérico as atividades às quais os escravos estavam sendo destinados. Não se deve, entretanto, separar drasticamente as propriedades em agrícolas e pecuaristas, os dois usos principais dados à terra, pois todas as propriedades, quase sem exceção (salvo, talvez, algumas no perímetro urbano), cultivavam roças de subsistência. De modo que ao se falar de propriedades dedicadas à "lavoura" ou à "criação", deve-se levar em conta que se trata da atividade principal exercida, mas não da única.

A lavoura no Paraná consistia primordialmente de mandioca, milho, feijão e arroz, mas muitos outros gêneros alimentícios eram também cultivados em escala menor. A erva-mate era exportada para o exterior, e cobrou relativa importância a partir de 1840 (Santos, 1995; Pereira, 1996). O calendário agrícola dependia estreitamente da freqüência das chuvas, mais altas no verão (dezembro a março), e das culturas consideradas. Via de regra, maio e junho era um período de colheita, e o preparo da terra e reinício dos plantios tinha lugar em agosto. A mandioca plantava-se entre agosto e outubro, e colhia-se depois de um ano; o milho plantava-se na mesma época da mandioca e colhia-se em junho ou às vezes antes; a primeira plantação de feijão ocorria entre janeiro e março, colhendo-se entre abril e junho; a segunda plantação de feijão ia de agosto a outubro e a colheita de novembro a janeiro; o plantio do arroz ocorria entre agosto e outubro e a colheita entre fevereiro e maio. O trigo semeava-se em junho e colhia-se em dezembro, com a ressalva de algumas partes dos Campos Gerais. As atividades que os escravos desempenhavam nestas culturas alimentares são difíceis de se conhecer com exatidão, pois as informações são parcas. Todavia, é possível presumir 
que eles participavam em todas as culturas e em todas as etapas da produção (Müller, 1978, pp. 31-32; Saint-Hilaire, 1978, pp. 23-27).

A pecuária tinha também um calendário próprio. Desde o início do comércio sulino de muares, na década de 1730, arraiais, pousos e fazendas de criar surgiram no planalto paranaense ao longo das estradas das tropas. O caminho mais transitado unia Viamão, no extremo sul da colônia, com a feira de Sorocaba na província de São Paulo. A viagem era longa e cheia de privações, a julgar pelos cronistas coevos. Saindo de Viamão, as tropas dirigiam-se para o norte pela região das Vacarias, alcançavam Lages e Curitibanos em território catarinense, atravessavam a seguir o rio Negro e por fim chegavam a repousar, após 45 ou 50 dias de viagem, nos Campos Gerais paranaenses (Machado, 1962, p. 133). A distância percorrida devia atingir pelo menos 100 léguas $(660 \mathrm{~km})$. Para chegar a Sorocaba, as tropas ainda deviam andar outra distância similar, transpondo a Lapa, Palmeira, Ponta Grossa, Castro, Itapeva (Faxina) e Itapetininga. Após a venda em Sorocaba, os animais comercializados seguiam para os mercados consumidores. Os bovinos continuavam principalmente para o Rio de Janeiro, via São Paulo e Taubaté, sendo que os muares e cavalos tinham destinos mais diversificados. Além dos Campos Gerais, existiam mais dois pontos de invernagem de tropas: ItapevaItapetininga e Taubaté. Assim, as tropas gaúchas, antes de chegar à Corte, tinham invernado, via de regra, em três ocasiões. Itapeva-Itapetininga e Taubaté cumpriam a função, ademais, de segurar o gado caso as condições de comercialização não estivessem conjunturalmente favoráveis em Sorocaba ou no Rio de Janeiro, respectivamente. A marcha das tropas desde os Campos Gerais até o Rio levava cerca de 2 meses (Petrone, 1976, cap. 5).

As estações do ano exerciam influência quanto a definir os meses de maior afluência de gado a Sorocaba. Os muares sulinos afluíam em maior número nos meses de outono, entre março e junho, após engorda nos campos do Paraná durante a estação chuvosa (primavera-verão), na qual os pastos reverdeciam. Os bovinos das fazendas paranaenses chegavam em maior número a Sorocaba um pouco antes, entre novembro e janeiro. Os tropeiros do Paraná que negociavam com gado sulino dirigiam-se para o sul, em companhia de camaradas e escravos, provavelmente no início da primavera (setembro); em novembro ou dezembro já se encontravam com suas tropas no Paraná, e nos meses finais do verão e durante o outono seguiam para Sorocaba, em tempo de 


\section{DONOS DE TERRAS E ESCRAVOS NO PARANÁ}

vender os animais para as colheitas do açúcar e do café em São Paulo (Klein, 1989, p. 347-372).

Conforme o inventário de terras de 1818, o porcentual de propriedades no Paraná dedicadas principalmente à lavoura alcançava $75,4 \%$ e à pecuária $13,7 \%$ (tabela 9). Cifra bem menor dos estabelecimentos, 5,7\%, tinham a lavoura e a criação com igual peso, e 5,1\% eram improdutivos, sem culturas nem criação. Se em termos gerais esses valores podem estar certos, não há perfeita homogeneidade no critério usado no inventário para classificar as propriedades quanto ao uso da terra. No cálculo anterior foram excluídos os imóveis de Curitiba e São José dos Pinhais, por exemplo, porque o inventário atribuiu como uso exclusivo dessas propriedades a lavoura, apesar de em ambas as localidades haver pecuária e fazendas de gado bastante conhecidas. Nas demais localidades possivelmente o arrolamento foi satisfatório. Mesmo com essas insuficiências, deve-se concluir que o número de propriedades votadas à lavoura era majoritário do que votado à pecuária, sem contrapeso. A única localidade onde prevalecia a proporção inversa era Castro, vila que reunia os principais fazendeiros e se erguia como o centro da criação de gado do Paraná nessa época.

Tabela 9 - Número de propriedades rurais segundo o uso da terra no Paraná, 1818

\begin{tabular}{lrcccr}
\hline Localidade & Lavoura & Criação & $\begin{array}{c}\text { Lavoura e } \\
\text { criação }\end{array}$ & $\begin{array}{c}\text { Sem lavoura } \\
\text { nem criação }\end{array}$ & Total \\
\hline Litoral & & & & & \\
Antonina & 233 & 1 & - & 21 & 255 \\
Guaratuba & 79 & - & - & 12 & 91 \\
Paranaguá & 408 & - & - & 19 & 427 \\
Planalto & & & & & \\
Castro & 97 & 134 & - & - & 231 \\
Lapa & 78 & 28 & 68 & 9 & 183 \\
Total & 895 & 163 & 68 & 61 & 1187 \\
$\%$ & 75,4 & 13,7 & 5,7 & 5,1 & 100,0 \\
\hline
\end{tabular}

Exclusive as propriedades de Curitiba (522) e São José dos Pinhais (205) por haver engano do recenseador no registro do uso da terra, e as de Palmeira (146) e mais 9 propriedades nas quais o uso da terra não foi indicado.

Fonte: Arquivo do Estado de São Paulo, Inventário dos Bens Rústicos, 1818. 
Contudo, as propriedades dedicadas à lavoura eram as de menores áreas. Selecionando a título de exemplo as propriedades de Castro e Lapa (ambas permitem uma comparação com a pecuária), constata-se que enquanto as propriedades agrícolas representavam $42,5 \%$ em ambas as localidades, ocupavam apenas 5,2\% da área total. Em contrapartida, os imóveis pastoris chegavam a $39,1 \%$ e ocupavam $85,1 \%$ da superfície total (tabela 10). Esta superfície equivalia a 1.029.944 ha ou 55,9\% das terras ocupadas no Paraná. Ou seja, a superfície era maior que a área apropriada por todas as propriedades agrícolas de todas as localidades paranaenses somadas. O cálculo da área média das propriedades com lavoura em comparação com pecuária reforça esses resultados: enquanto as primeiras revelaram uma superfície de 362 ha, as segundas possuíam área média de 6.397 ha.

Tabela 10 - Uso da terra nas propriedades rurais de Castro e Lapa segundo estratos de área, 1818

\begin{tabular}{|c|c|c|c|c|c|c|c|c|c|}
\hline \multirow{2}{*}{$\begin{array}{c}\text { Estratos } \\
\text { de área } \\
\text { (ha) }\end{array}$} & \multicolumn{2}{|c|}{ Lavoura } & \multicolumn{2}{|c|}{ Criação } & \multicolumn{2}{|c|}{$\begin{array}{l}\text { Lavoura e } \\
\text { criação }\end{array}$} & \multicolumn{2}{|c|}{$\begin{array}{l}\text { Sem lavoura } \\
\text { nem criação }\end{array}$} & \multirow{2}{*}{$\begin{array}{c}\text { Total } \\
\text { proprie- } \\
\text { dades }\end{array}$} \\
\hline & $\begin{array}{l}\text { N. } \\
\text { prop. }\end{array}$ & $\%$ & $\begin{array}{l}\text { N. } \\
\text { prop. }\end{array}$ & $\%$ & N.prop & $\%$ & $\begin{array}{l}\mathrm{N} . \\
\text { prop. }\end{array}$ & $\%$ & \\
\hline$<20$ & 27 & 15,4 & 9 & 5,6 & 1 & 1,5 & 1 & 12,5 & 38 \\
\hline 20 a 99 & 53 & 30,3 & 13 & 8,1 & 9 & 13,2 & 1 & 12,5 & 76 \\
\hline 100 a 999 & 74 & 42,3 & 47 & 29,2 & 40 & 58,8 & 3 & 37,5 & 164 \\
\hline 1000 a 4999 & 21 & 12,0 & 61 & 37,9 & 15 & 22,1 & 3 & 37,5 & 100 \\
\hline 5000 a 130000 & 0 & 0,0 & 31 & 19,3 & 3 & 4,4 & 0 & 0,0 & 34 \\
\hline Total & 175 & $\begin{array}{r}100, \\
0\end{array}$ & 161 & $\begin{array}{r}100 \\
0\end{array}$ & 68 & $\begin{array}{r}100 \\
0\end{array}$ & 8 & $\begin{array}{r}100 \\
0\end{array}$ & 412 \\
\hline$\%$ & 42,5 & & 39,1 & & 16,5 & & 1,9 & & 100,0 \\
\hline $\begin{array}{l}\text { Área total } \\
\text { (ha) }\end{array}$ & \multicolumn{2}{|c|}{63.333} & \multicolumn{2}{|c|}{1.029 .944} & \multicolumn{2}{|c|}{107.937} & \multicolumn{2}{|c|}{8.545} & 1.209 .758 \\
\hline$\%$ & \multicolumn{2}{|c|}{5,2} & \multicolumn{2}{|c|}{85,1} & \multicolumn{2}{|c|}{8,9} & \multicolumn{2}{|c|}{0,7} & 100,0 \\
\hline $\begin{array}{l}\text { Área média } \\
\text { (ha) }\end{array}$ & \multicolumn{2}{|c|}{362} & \multicolumn{2}{|c|}{6.397} & \multicolumn{2}{|c|}{1.587} & \multicolumn{2}{|c|}{1.068} & 2.936 \\
\hline
\end{tabular}

Exclusive 3 propriedades com área não delimitada.

Fonte: Arquivo do Estado de São Paulo, Inventário dos Bens Rústicos, 1818. 
A presença ou não de escravos em ambos os tipos de propriedades imprimiu mais uma hierarquia. Nos estabelecimentos dedicados primordialmente à lavoura, a maioria, 76,6\% nas duas localidades consideradas, não possuía escravos, enquanto apenas $39,8 \%$ das dedicadas à pecuária estavam na mesma situação. Novamente aqui as áreas ocupadas por cada tipo de propriedade conforme o uso da terra foram radicalmente diferentes. Nos estabelecimentos com pecuária e escravos, a área média foi de 9.925 ha; nas sem escravos, 1.051 ha. Nas propriedades com lavoura e escravos, a superfície média foi de 469 ha; nas sem escravos, 329 ha (tabela 11). Estabelece-se também uma hierarquia decrescente quanto às áreas ocupadas, conforme a existência de escravos nas propriedades e o uso principal dado à terra: primeiro, os imóveis dedicados à pecuária, com escravos; segundo, pecuária, sem escravos; terceiro, lavoura, sem escravos; e por último, lavoura, com escravos. As áreas ocupadas por cada uma dessas categorias foram, respectivamente, 79,6\%, 5,6\%, 3,6\%, e 1,6\% da área total de Castro e da Lapa. Ainda outra parcela de terra era ocupada pelos estabelecimentos mistos e os improdutivos. Destacam-se, com primazia absoluta, as propriedades de fazendeiros escravistas. Eles ocupavam, em Castro e na Lapa, o equivalente a 962.683 ha, que representaram 52,3\% das terras ocupadas do Paraná.

Tabela 11 - Uso da terra nas propriedades rurais com e sem escravos em Castro e Lapa, 1818

\begin{tabular}{|c|c|c|c|c|c|c|c|}
\hline \multirow{2}{*}{$\begin{array}{l}\text { Uso da } \\
\text { Terra }\end{array}$} & \multicolumn{4}{|c|}{ Propriedades com escravos } & \multicolumn{3}{|c|}{ Propriedades sem escravos } \\
\hline & $\begin{array}{c}\mathrm{N} . \\
\text { propr. }\end{array}$ & $\begin{array}{c}\text { Área } \\
\text { total (ha) }\end{array}$ & $\begin{array}{l}\text { Área } \\
\text { média } \\
\text { (ha) }\end{array}$ & $\begin{array}{c}\text { Total } \\
\text { escravos }\end{array}$ & $\begin{array}{l}\mathrm{N} . \\
\text { propr. }\end{array}$ & $\begin{array}{c}\text { Área } \\
\text { total (ha) }\end{array}$ & $\begin{array}{l}\text { Área } \\
\text { média } \\
\text { (ha) }\end{array}$ \\
\hline Lavoura & 41 & 19.242 & 469 & 174 & 134 & 44.091 & 329 \\
\hline Criação & 97 & 962.683 & 9.925 & 651 & 64 & 67.260 & 1.051 \\
\hline $\begin{array}{l}\text { Lavoura } \\
\text { e criação }\end{array}$ & 37 & 87.196 & 2.357 & 146 & 31 & 20.741 & 669 \\
\hline $\begin{array}{l}\text { Sem lavoura } \\
\text { nem criação }\end{array}$ & 0 & - & - & - & 8 & 8.545 & 1.068 \\
\hline Total & 175 & $\begin{array}{r}1.069 .12 \\
1\end{array}$ & 6.109 & 971 & 237 & $\begin{array}{r}140.63 \\
7\end{array}$ & 593 \\
\hline
\end{tabular}

Exclusive 3 propriedades com área não delimitada.

Fonte: Arquivo do Estado de São Paulo, Inventário dos Bens Rústicos, 1818. 


\section{Considerações finais}

O modesto estoque de escravos na composição demográfica do Paraná não pode ser menosprezado para se entender a estrutura econômica e social da região. O Paraná, apesar do percentual baixo de cativos, nunca superando um quarto da população total, foi uma sociedade escravista, e sua correlação com a propriedade da terra e os usos que a ela foram dados assim o demonstra. A introdução do escravo provocou, no Paraná, diferenciações contundentes na produção, acumulação, disponibilidade de crédito, domínio da terra, criação de gado, segmentação social e acesso ao poder. São hipóteses que se depreendem dos dados apresentados, e que requerem análises adicionais. As hierarquias mostradas, quanto à distribuição da terra e dos escravos, revelam uma sociedade altamente estratificada, no centro da qual, recortando as classes e conferindo dinâmica à economia, estava o escravo. Isto em que pese o Paraná formar uma sociedade cujo núcleo não fora a economia de exportação, mas a produção direcionada a mercados internos e de subsistência.

\section{REFERÊNCIAS BIBLIOGRÁFICAS}

BALHANA, Altiva Pilatti; MACHADO, Brasil Pinheiro; WESTPHALEN, Cecília Maria. História do Paraná. Curitiba: Grafipar, 1969, vol. 1.

ANABRAVA, Alice Piffer. Terras e escravos. In: PELÁEZ, Carlos Manuel \& BUESCU, Mircea (orgs.). A moderna história econômica. Rio de Janeiro: Apec, 1976, pp. 13-26.

COSTA, Iraci del Nero da; GUTIÉRREZ, Horacio. Paraná: mapas de habitantes, 17981830. São Paulo: IPE, 1985.

GUTIÉRREZ, Horacio. Demografia escrava numa economia não-exportadora: Paraná, 1800-1830. Estudos Econômicos, v. 17, n. 2, pp. 297-314,1987.

GUTIÉRREZ, Horacio. Crioulos e africanos no Paraná, 1798-1830. Revista Brasileira de História, v. 8, n. 16, 1988, p. 161-188.

GUTIÉRREZ, Horacio. A estrutura fundiária no Paraná antes da imigração. Estudos de História, Franca, v. 8, n. 2, pp. 209-232, 2001.

GUTIÉRREZ, Horacio. Fazendas de gado no Paraná escravista. Topoi: Revista de História, Rio de Janeiro, n. 9, pp. 102-127, 2004.

GUTIÉRREZ, Horacio; LEWKOWICZ, Ida. Trabalho infantil em Minas Gerais na primeira metade do século XIX. Locus, Juiz de Fora, v. 5, n. 2, pp. 9-21, 1999.

KLEIN, Herbert S. A oferta de muares no Brasil central: o mercado de Sorocaba, 18251880. Estudos Econômicos, v. 19, n. 2, pp. 347-372, 1989. 
LUNA, Francisco Vidal; COSTA, Iraci del Nero da. Posse de escravos em São Paulo no início do século XIX. Estudos Econômicos, v. 13, n. 1, pp. 211-221,1983.

MACHADO, Brasil Pinheiro. Contribuição ao estudo da história agrária do Paraná: formação da estrutura agrária tradicional dos Campos Gerais. Anais do II Simpósio Nacional dos Professores Universitários de História, pp. 129-155,1962.

MARCONDES, Moysés. Documentos para a história do Paraná. Rio de Janeiro: Typographia do Annuario do Brasil, 1923.

MARTINS, Romário. História do Paraná. $3^{a}$ ed., São Paulo: Guairá, s/d.

MELlO, Zélia Maria Cardoso de. Metamorfoses da riqueza: São Paulo, 1845-1895. São Paulo: Hucitec, 1985.

MÜlleR, Daniel Pedro. Ensaio d'um quadro estatístico da Província de São Paulo (1837). São Paulo: Governo do Estado de São Paulo, 1978.

PAIVA, Clotilde Andrade; Klein, Herbert S. Escravos e livres nas Minas Gerais no século XIX: Campanha em 1831. Estudos Econômicos, v. 22, n. 1, pp. 129-151, 1992.

PEREIRA, Magnus Roberto de Mello. Semeando iras rumo ao progresso (ordenamento jurídico e econômico da sociedade paranaense, 1829-1889). Curitiba: Editora UFPR, 1996.

PETRONE, Maria Thereza Schörer. O barão de Iguape: um empresário da época da Independência. São Paulo: Companhia Editora Nacional, 1976.

SAINT-HILAIRE, Auguste de. Viagem a Curitiba e Província de Santa Catarina. São Paulo: Edusp, 1978.

SANTOS, Carlos Roberto Antunes dos. História da alimentação no Paraná. Curitiba: Fundação Cultural, 1995.

SCHWARTZ, Stuart B. Segredos internos: engenhos e escravos na sociedade colonial. São Paulo: Companhia das Letras, 1988.

GUTIÉRREZ, Horacio. Lands Owners and Slaves in Paraná: Patterns and Hierarchies in the Early Nineteenth Century. História, São Paulo, v. 25, n. 1, p. 100-121, 2006.

Abstract: In the nineteenth century first decades the land distribution in Paraná registered a high concentration level due to the fact that the cattle farmers owned the biggest properties. This article examines the use of the enslaved labor by land owners as well as the access to the land by the slaves owners. It discusses both social hierarchies in the local society and the land and slaves importance in these hierarchies constitution. The primary sources used in the analysis were lands official records and demographic censuses.

Keywords: Agrarian structure, Slavery, Colonial Paraná.

Artigo recebido em 10/2006. Aprovado em 11/2006.

\section{NOTAS:}

\footnotetext{
* Universidade de São Paulo.

${ }^{1}$ Carta ao rei do ouvidor geral de São Paulo Raphael Pires Pardinho, 30 de agosto de 1721, em Moysés Marcondes (1923).
} 
${ }^{2} \mathrm{O}$ Inventário dos bens rústicos, que é de 1818, foi comparado com as listas nominativas do ano anterior, 1817, pois a listas de 1818 estão incompletas, faltando o levantamento de uma das localidades, a de Castro.

${ }^{3}$ Em recenseamento de 1831-32, relativo à Comarca de Mariana (MG), constaram crianças (livres e escravas) sendo requisitadas para trabalhos a partir dos 5 anos; com 10 anos ou mais em torno de $30 \%$ das crianças figuraram com ocupação definida (Gutiérrez \& Lewkowicz, 1999).

4 A proporção não é exata, mas aproximada, pois havia alguns chefes de famílias com mais de um domicílio, assim como proprietários de terras com mais de uma propriedade. As diferenças não se anulam, mas não são significativas.

${ }^{5}$ A porcentagem de donos de escravos com terras seria similar à dos domicílios escravistas com terras, mas não exatamente igual, pois havia domicílios com mais de um proprietário de escravos, e proprietários de escravos com mais de um domicílio. A diferença, no entanto, foi desprezível. Em 1804, por exemplo, ano para o qual o confronto exato foi feito, havia 894 escravistas e 898 domicílios com escravos; em 1824 existiam 1.131 donos de escravos e 1.132 domicílios escravistas.

${ }^{6}$ Podemos lembrar o caso da cidade de São Paulo e seu entorno rural: no quinquênio 1845-50, ou seja, antes da abolição do tráfico, o valor dos escravos da composição total da riqueza dos inventariados atingia um peso de $32,2 \%$, enquanto a soma de terras e terrenos oscilava em torno de $10 \%$ (Mello, 1985, pp. 83 e 155).

${ }^{7}$ Conforme o inventário de bens rústicos, $40,9 \%$ dos estabelecimentos cadastrados no Paraná tinha menos de 20 hectares, $26 \%$ menos de 4 ha, e 4,8\% menos de 1 ha (Gutiérrez, 2001). 